\title{
Influence of the bipartite scrotum on the testicular and scrotal temperatures in goats ${ }^{1}$
}

\author{
Antonio A.N. Machado Júnior²*, Maria A. Miglino ${ }^{3}$, Danilo J.A. Menezes ${ }^{4}$, Antonio \\ C. Assis Neto ${ }^{5}$, Rudolf Leiser ${ }^{6}$, Ricardo A.B. Silva ${ }^{7}$ and Maria A.M. Carvalho ${ }^{7}$
}

\begin{abstract}
Machado Júnior A.A.N., Miglino M.A., Menezes D.J.A., Assis Neto A.C., Leiser R., Silva R.A.B. \& Carvalho M.A.M. 2009. Influence of the bipartite scrotum on the testicular and scrotal temperatures in goats. Pesquisa Veterinária Brasileira 29(10):797-802. Curso de Medicina Veterinária, Universidade Federal do Piauí, Campus Profa Cinobelina Elvas, Bom Jesus, PI 64900-000, Brazil. E-mail: machadojunior2@yahoo.com.br

The influence of the scrotal bipartition and of the year period on the scrotal-testicular thermal regulation was evaluated in male goats raised in Piaui State, Brazil. Eighteen male goats at mating age were accomplished in this study and arranged into three Groups (6 animals each) obeying the classification as goats presenting no scrotal bipartition (Group I), goats showing scrotal bipartition at $50 \%$ of the testicular length (Group II), and goats with more than $50 \%$ of scrotal bipartition (Group III). The scrotal, testicular and spermatic funiculi temperatures were evaluated invasively with the aid of a digital thermometer and noninvasive with a pyrometer in the proximal, medial and distal portion. The data were acquired during the dry (October-November) and rainy (February-March) period of the year, measured in two shifts: morning (6h00-7h00) and afternoon (14h00-15h00). The results were submitted to variance analysis (ANOVA) following the SNK test for average comparison $(p<0.05)$. The year period interfered on the scrotal-testicular thermal regulation, due to increased temperatures of the scrotal, testicular and spermatic funiculi during the dry period in comparison with the rainy period. The bipartition level was also a factor which contributed to the influence of scrotal-testicular temperature regulation, due to lower average scrotaltesticular temperature rates observed during both periods in the goats with higher levels of scrotal bipartition ( $>50 \%)$. It is possible to conclude that with the experimental conditions applied on this study, the level of scrotal bipartition and the climatic conditions interfere with the scrotal-testicular thermal regulation in goats.
\end{abstract}

INDEX TERMS: Small ruminant, scrotal division, scrotal-testicular thermal regulation.

RESUMO.- [Influência do escroto bipartido sobre as temperaturas dos testículos e escroto em caprinos.] $O$ objetivo deste trabalho foi avaliar a influência do grau de bipartição escrotal e do período do ano sobre a termorregulação escroto-testicular em caprinos criados no Estado do Piauí. Foram utilizados 18 reprodutores caprinos ma-

\footnotetext{
${ }^{1}$ Received on February 11, 2009.

Accepted for publication on June 27, 2009.

2 Curso de Medicina Veterinária, Universidade Federal do Piauí, Campus Profa Cinobelina Elvas, Bairro Planalto Horizonte, Bom Jesus, PI64900-000, Brazil. *Corresponding author: machadojunior2@yahoo.com.br / machadojunior@ufpi.edu.br

${ }^{3}$ Departamento de Cirurgia, Faculdade de Medicina Veterinária e Zootecnia, Universidade de São Paulo (USP), Av. Prof. Dr. Orlando Marques de Paiva 87, São Paulo, SP 05508-270, Brazil.

${ }^{4}$ Unidade Acadêmica de Medicina Veterinária, Universidade Federal
}

chos, divididos em três grupos de seis animais: O Grupo I contendo caprinos com escroto simples, o Grupo II, caprinos com escroto bipartido até $50 \%$ do comprimento testicular e o Grupo III, caprinos com bipartição superior a 50\% do comprimento testicular. Os parâmetros avaliados foram as temperaturas do escroto, testículo e funículo espermáti-

\footnotetext{
de Campina Grande (UFCG), Campus de Patos, Cx. Postal 64, Patos, PB 58700-970, Brazil.

${ }^{5}$ Faculdade de Zootecnia, Universidade Estadual Paulista, Campus Experimental de Dracena, Rodov. Cmte. João Ribeiro de Barros 294 Km 651, Dracena, SP 17900-000, Brazil.

${ }^{6}$ Institut für Veterinär Anatomie, Histologie und Embryologie der JustusLiebig-Universität Giessen, Frankfurter Str. 98, Giessen, Germany.

${ }^{7}$ Departamento de Morfofisiologia Veterinária, Universidade Federal do Piauí, Campus Agrícola da Socopo, s/n, Teresina, PI 64049-550, Brazil.
} 
co, obtidas de forma invasiva, com um termômetro digital termoacoplável, e não invasiva, com um pirômetro, nos terços proximal, médio e distal. Os dados foram coletados nos períodos seco (outubro-novembro) e chuvoso (fevereiro-março) do ano, bem como, nos turnos da manhã (6h00 às $7 \mathrm{~h} 00$ ) e tarde (14h00 às $15 \mathrm{~h} 00$ ). Os resultados foram submetidos à análise de variância (ANOVA) seguida do teste SNK para comparação das médias $(p<0,05)$. O período do ano interferiu na termorregulação escroto-testicular, pois no período seco as temperaturas do escroto, testículo e funículo espermático foram mais elevadas que as observadas no período chuvoso. O grau de bipartição do escroto foi outro fator que modificou a temperatura escrototesticular, já que os caprinos que apresentaram escroto com maior grau de bipartição demonstraram as menores médias das temperaturas escroto-testiculares em ambos os períodos e turnos avaliados. Conclui-se, portanto, que tanto o período do ano quanto o grau de bipartição do escroto influenciaram o processo de termorregulação escroto-testicular em caprinos.

TERMOS DE INDEXAÇÃO: Caprinos, divisão escrotal, termorregulação escroto-testicular.

\section{INTRODUCTION}

The localization of the testicles in the scrotum is a preponderant factor for the spermatogenesis, as the temperature is down regulated from $2^{\circ} \mathrm{C}$ to $6^{\circ} \mathrm{C}$ in comparison to the abdomen (Kastelic et al. 1996). The testicular temperature elevation increases the metabolism and the oxygen demand by the seminiferous epithelial cells, although the sanguine flow is limited a situation which leads to an incapability to supply this demand, resulting in hypoxia and seminal quality reduction (Villares 1976, Setchell 1998).

The interaction of several factors inducts morphophysiological adaptations in animals, which contribute to the alterations on the production and reproduction efficiencies. Among the adaptations, the scrotal bipartition presented in goat of the African East and Brazilian arid and semi-arid can be cited (Robertshaw 1982, Nunes et al. 1983). This characteristic is responsible for the increase on the testicular surface exposed to the environmental temperature, making easy the heat dissipation, increases the testicle's biometrical parameters, and improve the reproductive efficiency of these animals in comparison to the ones which do not present this anatomical specialization (Nunes et al. 1983, Silva et al. 1986, Almeida 2003).

In the process of the testicle thermal regulation, many factors are involved in order to maintain the organ tempera-ture at adequate levels for the spermatic production. Examples of these factors are the evaporation produced by the sweat glands (Blasquez et al. 1988, Dyce et al. 2004, Nunes 2005), the contraction and relaxation of the cremasteric muscle and dartos tunic responsible for the testicle approximation and coming away in relation to the body (Banks 1991, Hafez \& Hafez 2003), and the scrotal sanguine flow which is responsible for the heat irradiation (Brito et al. 2004) and the upstream mechanism flow made by the spermatic internal artery in relation to the downstream flow occasioned by the testicular veins (Getty 1986, Godinho et al. 1987, Setchell et al. 1988, Almeida 2003, Hafez \& Hafez 2003, Brito et al. 2004, Dyce et al. 2004).

According to the literature, the efficiency of testicular thermal regulation mechanism is related to the morphological and functional characteristics of the components of the scrotum, the sweat glands could be outstand (Godinho \& Cardoso 1980). A comparison between the scrotal bipartition presented in some goat to the ones with no bipartition revealed that the former animals present more sweat glands, increasing the sweat production and, consequently, facilitates the heat loss by evaporation (Nunes 2005).

Based on this, this study aims to study the influence of the level of scrotal bipartition on the thermal regulation of goat scrotal-testicular organ during dry and rainy year periods.

\section{MATERIALS AND METHODS}

Research local and experimental animals. The study was developed at an experimental goat livestock of 18 cross breed reproductive males, located at the Agrarian Centre in the Piauí Federal University, Teresina city, Piaui State, Brazil. The animals were arranged into three Groups with six animals each according to the descriptions of Almeida (2003) and obeying the classification as goat presenting no scrotal bipartition (Group I), goat showing scrotal bipartition at $50 \%$ of the testicular length (Group II), and goat with more than $50 \%$ of scrotal bipartition (Group III) (Fig.1).

Environmental parameters and rectal temperatures. During the experiment, data in relation to ambient temperature and relative humidity were estimated with the aid of a digital thermal-hygrograph (Model DT8829, Dellt Sistema e Instrumentos Ltda, Rua Corrientes 135, Pq. Novo Oratório, Santo André, SP). The rectal temperature was estimated using a digital clinical thermometer (BD-Brasil, Rua Alexandre Dumas 1976, São Paulo,SP).

Scrotal, testicles, and spermatic funiculi temperatures. The scrotal, testicle, and spermatic funiculi temperatures were measured during the dry (October-November) and rainy (February-March) periods into shifts, morning (6h00-7h00 a.m.) and afternoon (2h00-3h00 p.m.), in order to observe the influence of the daily ambient temperature variance on the organ. Before the testicle temperature estimation, in each Group, a draw of the antimere (left or right) was evaluated at the morning, and the afternoon shift. This procedure was taken in order to avoid repetitive inflammatory lesion.

The testicle and spermatic funiculi temperatures were obtained using an invasive method with the application of a thermopar digital thermometer (Thermopar Type K-HD9218 with a penetration pole and temperature sensor TP 741 , with precision of $0.1^{\circ} \mathrm{C}$, Delta OHM SRL, Via G. Marcon 5, 35030 Caselle Di Selvazzano (PD), Italy), while the scrotum temperature was obtained in a non-invasive form by digital pyrometer (MT4 - laseraim, with precision of $0.5^{\circ} \mathrm{C}$, Raytek Corporation, 1201 Shaffer Road, Santa Cruz, CA 95060). 


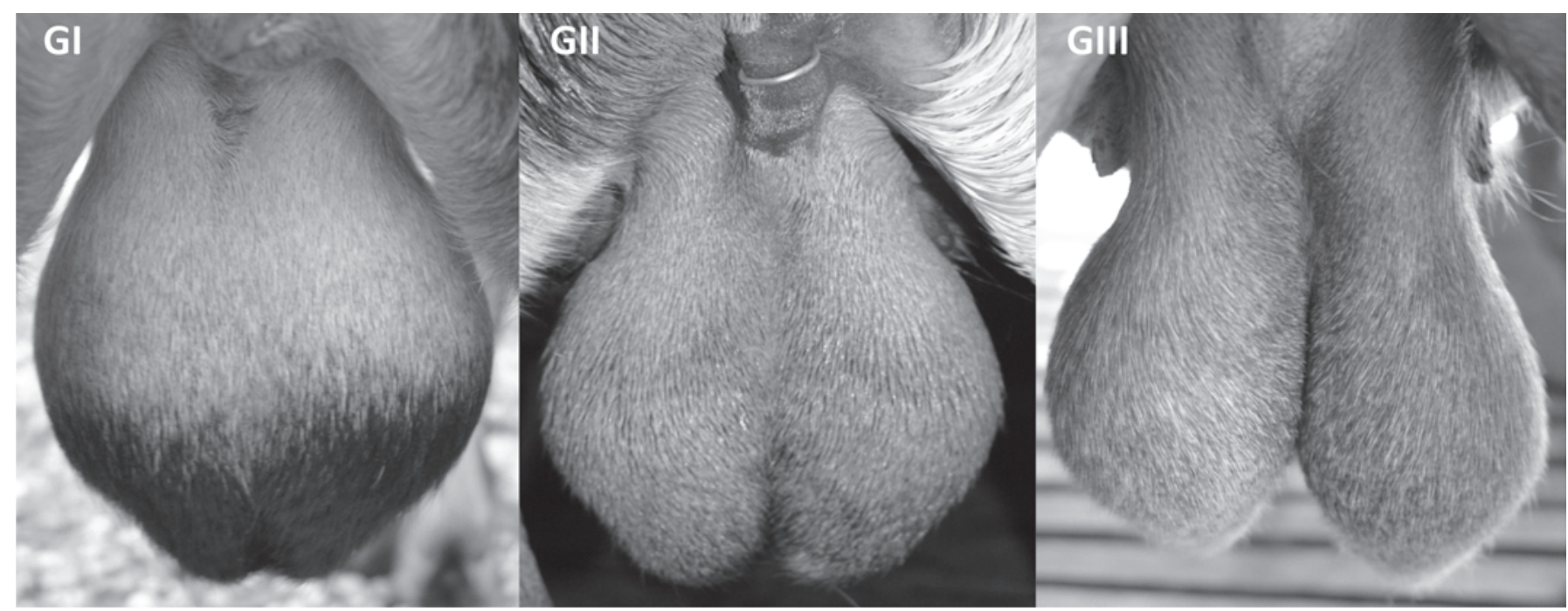

Fig.1. Scrotal region of goats of the different Groups: (GI) Animals presenting no bipartition; (GII) animals with bipartition at 50\%; (GIII) animals with bipartition up to $50 \%$ of the testicular length.

The scrotal temperature was measured at the scrotal surface at proximal, medial and distal portions, positioning the pyrometer at approximately $1.0 \mathrm{~cm}$ away from the scrotal skin. The testicle temperature were evaluated on the medial surface at proximal, medial and distal portions, introducing the thermometer under the scrotal skin by non-perforating the testicle in order to avoid producing damage on the testicle parenchyma, while the spermatic funiculi temperature was measured on the proximal and distal portions, introducing the thermometer on the scrotal skin. Before all invasive temperature measurements taken the skin was cleaned using iodide alcohol in order to avoid infective processes. Inflammations secondary to the needle thermometer introduction were not observed during and after the experimentation.

Statistic analysis. The data were submitted to the variance analysis (ANOVA) following the Student-Newman-Keuls (SNK) test for average comparison at $5 \%$ probability level.

\section{RESULTS}

The results demonstrated that the scrotal, the testicle and the spermatic funiculi temperatures decreased from the proximal to the distal portions independent to the scrotal morphology (Fig.2-4).

The comparison of the data referring to the environment temperature and the relative humidity in dry $\left(35.07 \pm 2.43^{\circ} \mathrm{C} /\right.$ $56.09 \pm 2.3 \%)$ and rainy $\left(30.29 \pm 2.26^{\circ} \mathrm{C} / 76.23 \pm 3.4 \%\right)$ periods was considered significant $(p<0.05)$.

The intrafunicular temperature in the proximal portion varied only in relation to the year period and the difference among the Groups was considered not significant (Fig.2). However, in the distal portion the variation of the spermatic funiculi temperature was significant among the Groups, being more expressed in the dry period in comparison to the rainy period. Significant ratios of the funiculi temperature were observed in the proximal and the distal portion between the dry and the rainy period, otherwise being independent of the scrotal bipartition (Fig.2).

In the rainy period, a significant ratio $(p<0.05)$ was observed in the results obtained during the morning in

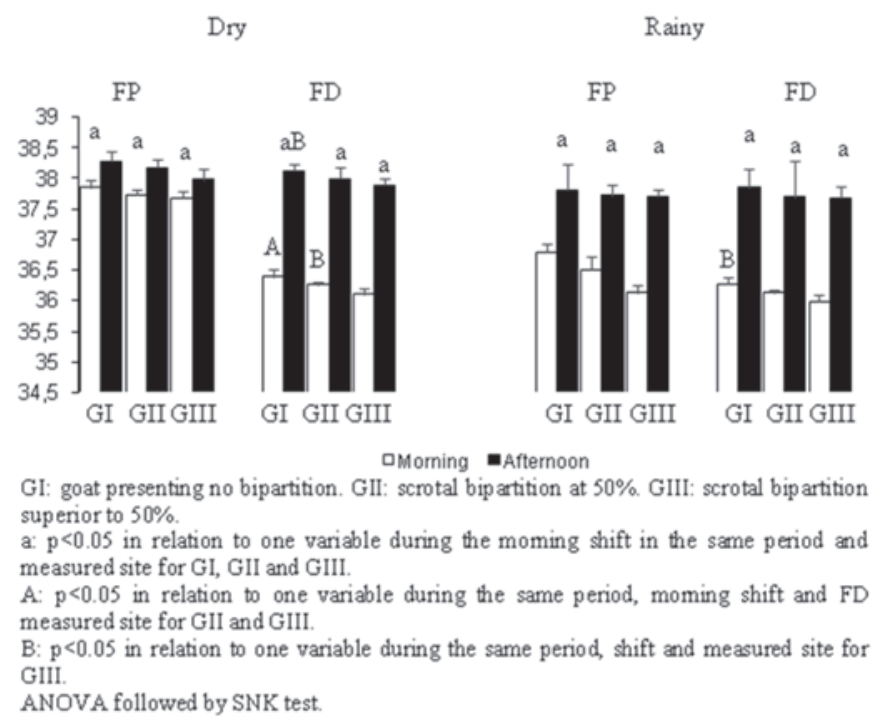

Fig.2. Behavior of the proximal (FP) and the distal (FD) spermatic funiculi temperature $\left({ }^{\circ} \mathrm{C}\right)$ of goat presenting no scrotal bipartition and scrotal bipartition in the morning and afternoon shifts during dry and rainy periods.

comparison to the afternoon data, being the lower result observed in the goats of the Group III (Fig.2). In the dry period, significant differences were observed among the Groups either during dry or rainy periods, in both periods of the day; once more, the animals of the GIII demonstrated the lowest temperature average among the Groups being $36.10 \pm 0.09$ and $37.88 \pm 0.11^{\circ} \mathrm{C}$ for dry and rainy periods, respectively.

The temperature distribution along the testicles presented a classic and standard distribution, being higher temperature in relation to the caput region and decreasing to lower temperature in direction to the caudate extremity, where as the differences of temperature during the year periods were considered significant (Fig.3). 


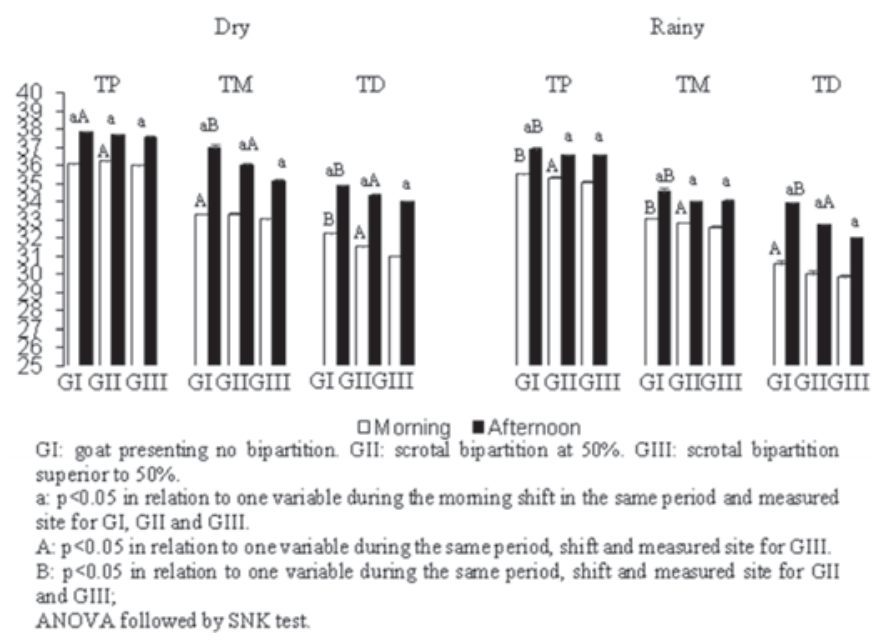

Fig.3. Behavior of the proximal (TP), the medium (TM) and the distal (TD) testicle temperature $\left({ }^{\circ} \mathrm{C}\right)$ of goat presenting no scrotal bipartition and scrotal bipartition in the morning and afternoon shifts during dry and rainy periods.

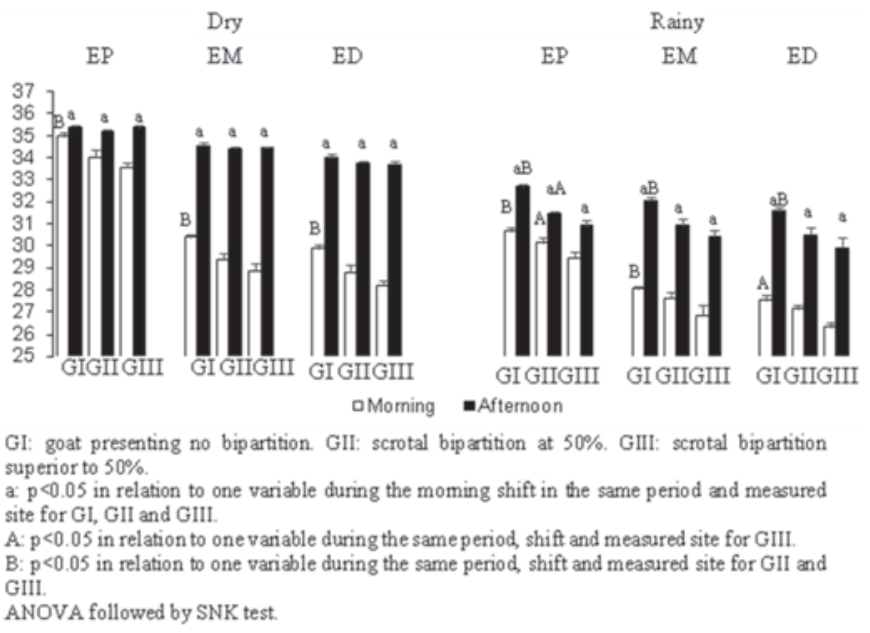

Fig.4. Behavior of the proximal (EP), the medium (EM) and the distal (ED) scrotal temperature $\left({ }^{\circ} \mathrm{C}\right)$ of goat presenting no scrotal bipartition and scrotal bipartition in the morning and afternoon shifts during dry and rainy periods.

During rainy and dry periods, the comparison of the data concerning the testicle temperature among the Groups revealed a significant difference in the animals of the Group III, presenting the lowest temperature rates during the morning $\left(35.07 \pm 0.10 / 36.01 \pm 0.07^{\circ} \mathrm{C}\right)$ and the afternoon $\left(36.54 \pm 0.08 / 37.56 \pm 0.10^{\circ} \mathrm{C}\right)$ as shown in Figure 3. On the other hand, the goats of the Group II in the morning during the dry period presented an unexpected behavior on the testicle temperature at the proximal region, revealing high average levels in contrast to the data acquired in the afternoon when the temperature was higher than the animals of the Group III (Fig.3).

Similar behavior was observed in relation to the medial and distal testicle temperature (TM/TD), presenting low temperature rates in the rainy period in comparison to the dry period when the lowest results were measured during the morning. The goats of the Group III presented the lowest temperature results for TM and TD. The animals of the Group II showed an irregular behavior due to the similarity of the results either being close to goats of Group I or III (Fig.3).

The scrotal temperature (Fig.4) was inferior in relation to the testicle and funicular temperatures which were elevated in the evening during the dry period when compared to the rainy period, demonstrating similar behavior as the testicular temperature.

\section{DISCUSSION}

The dry and rainy periods studied in the current investigation demonstrated a significant alteration on the environmental temperature and the relative humidity of air from $35.07 \pm 2.43^{\circ} \mathrm{C}$ and $56.09 \pm 2.3 \%$ to $30.29 \pm 2.26^{\circ} \mathrm{C}$ and $76.23 \pm 3.4 \%$. Although in our study, this significant alteration, did not show any influence from the environment temperature to the rectal temperature of the goat, but we observed a higher rectal temperature which was higher than the testicular and scrotal temperatures, a fact to be in agreement to the descriptions made for goat (Lima Júnior et al. 1995) and bovine (Godinho \& Cardoso 1980, Kastelic et al. 1997, Strapa et al. 2004).

A decrease on the scrotal, testicle and spermatic funiculi temperatures were observed when comparing the year periods and also in the day-time period (morning/ afternoon). In agreement to Lima Júnior et al. (1995), the highest temperatures were observed in the afternoon. Based on this, there is a notable the influence of the year period on the scrotal, testicular, and spermatic funiculi temperatures. The funiculi temperatures during the dry period of proximal and distal portions were almost equal for $\mathrm{Gl} 38.06 \pm 0.13 / 37.25 \pm 0.11^{\circ} \mathrm{C}$, for Gll $37.95 \pm 0.11 /$ $37.12 \pm 0.12^{\circ} \mathrm{C}$, and for GIII $37.82 \pm 0.14 / 36.99 \pm 0.10^{\circ} \mathrm{C}$. But, in the rainy period, it was possible to observe a decrease like for GI 37.29 $\pm 0.29 / 37.01 \pm 0.21^{\circ} \mathrm{C}$, for Gll 37.11 $\pm 0.19 /$ $36.91 \pm 0.32^{\circ} \mathrm{C}$, and for GIII $36.91 \pm 0.12 / 36.83 \pm 0.15^{\circ} \mathrm{C}$ (Fig.2). In this context, in bulls kept in a $15^{\circ} \mathrm{C}$ and $25^{\circ} \mathrm{C}$ environment temperature (Kastelic et al. 1997), a variation was demonstrated on the arterial blood temperature at the proximal portion of the funiculi $\left(34.3-36.5^{\circ} \mathrm{C}\right)$ and in the testicle caput region $\left(31.7-34.8^{\circ} \mathrm{C}\right)$. In our study, the results observed during the dry and rainy periods were lesser than the results described above. Hence, we believe that this difference could be explained by the different method of temperature investigation applied: while Kastelic et al. (1997) daily and directly measured, the temperature on the testicular artery, we chose for temperature measurement the perivascular space of spermatic funiculi.

It has been proved that differences on the morphology of spermatic funiculi and scrotum could influence the mechanism of testicle thermal regulation. Actually, length and diameter alterations on the testicle artery, decrease of the arterial wall thickness, and distance between the artery and vein are directly related to the regulation of temperature (Cook et al. 1994). Many studies had 
described that goats presenting scrotal bipartition demonstrate higher diameter and length of the spermatic funiculi and higher length of arteries than animals not presenting this anatomical specializations, resulting in better and larger heat losses of in these animals overview by Nunes (2005). Therefore, our results could be explained by the presence of this characteristic due to the lesser values of temperature encountered in the group of animals with large scrotal bipartition level during the shifts and year periods (Fig.3-4).

A variation between the testicle and scrotal temperatures was observed during the dry and rainy periods as concerning the morning and afternoon shifts of environmental temperatures. In agreement with Lima Júnior et al. (1995), in goat the temperatures of the proximal and distal scrotal bipartition in animals showing scrotal bipartition (SB) and no scrotal bipartition (NB), were $34.89 \pm 0.12$, $31.36 \pm 0.43^{\circ} \mathrm{C}$ for $\mathrm{SB}$ versus $34.77 \pm 0.20,32.02 \pm 0.41^{\circ} \mathrm{C}$ for (NB), where as, during the afternoon, theses animals demonstrated an increase on the temperature being $35.10 \pm 0.27$ and $31.82 \pm 0.21^{\circ} \mathrm{C}$ for SB versus $35.27 \pm 0.23$ and $32.61 \pm 0.61^{\circ} \mathrm{C}$ for NB. In the same study, in the morning shift, the testicle temperature was $34.85 \pm 0.11$ and during the afternoon shift it was $31.70 \pm 0.34^{\circ} \mathrm{C}$ for SB $21.0 \pm 0.33$, $32.30 \pm 0.25^{\circ} \mathrm{C}$ versus $35.31 \pm 0.14$ and $32.72 \pm 0.23^{\circ} \mathrm{C}$ for $\mathrm{NB}$, respectively. Based on our results, there is a suggestion of interaction between the variation on the environmental temperature and the scrotal testicular temperature. This could be by an insulating effect in the organ resulting the scrotal tem-perature in the bovine to significantly alterate on the testicle after 24 and 48 hours as observed by Kastelic et al. (1996). Making an analogy with our results, it is possible that the dry period refers to the insulation bag and the rainy period does not, hence, there is an interference to the data obtained, demonstrating that the scrotal and testicle temperature during the dry period were higher in comparison to the rainy period.

In our study the goats of experimental Groups I, II and III presented a decrease on the scrotal and testicular temperature from the proximal to the distal region, a fact which was specifically distinct in the Group with high levels of scrotal bipartition and lowest results for temperature. It has been reported that the scrotal temperature in proximodistal way decreases from $30.4^{\circ} \mathrm{C}$ to $28.8^{\circ} \mathrm{C}$ (Kastelic et al. 1995) and as concerning for the testicle temperature from $34.3^{\circ} \mathrm{C}$ to $34.5^{\circ} \mathrm{C}$ (Kastelic et al. 1997).

Our results revealed that the lowest rate of scrotal testicular temperatures were observed during the rainy periods at the lowest environmental temperature $\left(30.29^{\circ} \mathrm{C}\right)$, similar to the descriptions for bovine (Kastelic et al. 1997) which showed low scrotal and testicle temperatures at $15^{\circ} \mathrm{C}$.

\section{CONCLUSION}

Based on the methods applied and on the results, it is possible to conclude that the scrotal bipartition level inter- feres significantly with the scrotum-testicular thermal regulatory process in the goat. This responds to a physiological variation of the scrotum-testicular temperature by variation of the environmental temperature along the year, due to wideness of the skin surface area promoted by the scrotal bipartition, contributing to and facilitating the heat changes between the scrotal wall and the ambient. Summarizing, it can be affirmed that animals with scrotal bipartition are capable for better scrotum-testicular temperature regulation towards environmental temperature variation.

Acknowledgements.- To Conselho Nacional de Desenvolvimento Científico e Tecnológico (CNPq) for financial support for the project MCT/ CNPq/PADCT (Proc.620145/04-8).

\section{REFERENCES}

Almeida M.M. 2003. Vascularização arterial testicular e escrotal de caprinos nativos do Estado do Piauí, segundo grau de divisão do escroto, e a relação com parâmetros reprodutivos. Dissertação de Mestrado em Ciência Animal, Centro de Ciências Agrárias, Universidade Federal do Piauí, Teresina. 96p.

Banks W.J. 1991. Sistema reprodutor masculino, p.546-564. In: Banks W.J. (Ed.), Histologia Veterinária Aplicada. $2^{\underline{a}}$ ed. Manole, São Paulo.

Blasquez N.B., Mallard G.J. \& Weed S.R. 1988. Sweat glands of the scrotum of the bull. J. Reprod. Fertil. 83:673-677.

Brito L.F., Silva A.E., Barbosa R.T. \& Kastelic J.P. 2004. Testicular thermoregulation in Bos indicus, crossbred and Bos taurus bulls: Relationship with scrotal, testicular vascular cone and testicular morphology, and effects on semen quality and sperm production. Theriogenology 61:511-528.

Cook R.B., Couter G.H. \& Kastelic J.P. 1994. The testicular vascular cone, scrotal thermoregulation and their relationship to sperm production and seminal quality in beef bulls. Theriogenology $64: 653-$ 671.

Dyce K.M., Sack W.O. \& Wensing C.J.G. 2004. Tratado de Anatomia Veterinária. $3^{\underline{a}}$ ed. Elsevier, Rio de Janeiro. 663p.

Getty R. 1986. Anatomia dos Animais Domésticos. Vol.1. 5 $5^{\mathrm{a}}$ ed. Guanabara Koogan, Rio de Janeiro. 1134p.

Godinho H.P.\& Cardoso F.M. 1980. Rectum-testis temperature gradient in zebus. Zentralbl Veterinärmed. A 27:593-595.

Godinho H.P., Cardoso F.M. \& Nascimento J.F. 1987. Anatomia dos Ruminantes Domésticos. Departamento de Morfologia, Instituto de Ciências Biológicas da UFMG, Belo Horizonte. 415p.

Hafez E.S.E. \& Hafez B. 2003. Reprodução Animal. $7^{a}$ ed. Manole, São Paulo. 530p.

Kastelic J.P., Coulter G.H. \& Cook R.B. 1995. Scrotal surface, subcutaneous, intra-testicular and intra-epididymal temperatures in bulls. Theriogenology 44:147-152.

Kastelic J.P., Cook R.B., Coulter G.H. \& Saacke R.G. 1996. Insulating the scrotal neck affects semen quality and scrotal/testicilar temperatures in the bull. Theriogenology 45:935-942.

Kastelic J.P., Cook R.B. \& Coulter G.H. 1997. Contribution of the scrotum, testes and testicular artery to scrotal/testicular thermoregulation in bulls at ambient temperatures. Anim. Reprod. Sci. 45:255-261.

Lima Júnior A.D. \& Vianni M.C.E. 1995. Efeito da morfologia da bolsa escrotal na termorregulação em caprinos nativos no Nordeste do Brasil. Ciência da Vida 17:97-107.

Nunes J.F., Riera G.S., Silva A.E.F.D., Ponce de Leon F.A. \& Lima 
F.A.M. 1983. Características espermáticas de caprinos Moxotó de acordo com a morfologia escrotal. Circular Técnica 6, Embrapa Caprinos, Sobral, Ceará.

Nunes A.S. 2005. Morfologia do funículo espermático e dos escrotos em caprinos nativos do Estado do Piauí, com diferentes configurações escrotais. Dissertação de Mestrado em Ciência Animal, Centro de Ciências Agrárias, Universidade Federal do Piauí, Teresina. 57p.

Robertshaw D. 1982. Concepts in animal adaptation: Thermoregulation of the goat. Proc. $3^{\text {rd }}$ Int. Conf. Goat Production and Disease, Tucson, p.395-397.

Setchell B.P. \& Brooks D.E. 1988. Anatomy, vascular, innervation and fluids of the male reproduction tract, p.753-836. In: Knobil E. \& Neil J.D. (Eds), The Physiology of Reproduction. Raven Press, New York.
Setchell B.P. 1998. The Parkers lecture: Heat and the testis. J. Reprod. Fertil. 114:179-194.

Silva A.E.D.F., Nunes J.F. \& Melo F.A. 1986. Influência da morfologia escrotal nas características do sêmen e seus efeitos na fertilidade de caprinos. Hora Vet., Porto Alegre, 5:66-69.

Strapa R.A., Diniz E.G., Beletti M.E., Eberhardt B.G. \& Strapa R. 2004. Avaliação das diferenças entre temperatura retal, escrotal e intratesticular e da quantidade de glândulas sudoríparas e sebáceas em escroto de búfalos de duas faixas etárias. Revta Bras. Reprod. Anim. 28:202-205.

Villares J.B. 1976. Bioclimatologia da reprodução animal: revisão sobre efeitos do ambiente de calor. Anais $2^{\circ}$ Simpósio Nacional de Reprodução Animal, Belo Horizonte, p.192-215. 